City University of New York (CUNY) CUNY Academic Works

2012

\title{
Phenomenological Theories of Crime
}

Peter K. Manning

Northeastern University

Michael W. Raphael

CUNY Graduate Center

How does access to this work benefit you? Let us know!

More information about this work at: https://academicworks.cuny.edu/gc_studentpubs/27

Discover additional works at: https://academicworks.cuny.edu

This work is made publicly available by the City University of New York (CUNY).

Contact: AcademicWorks@cuny.edu 


\title{
Oxford Bibliographies
}

\author{
Your Best Research Starts Here
}

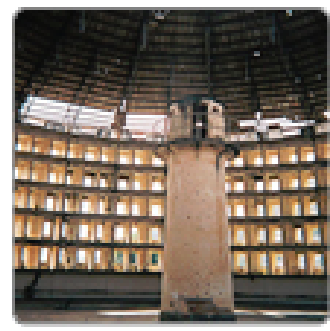

\section{Phenomenological Theories of Crime}

\author{
Peter K. Manning, Michael W. Raphael \\ LAST MODIFIED: 24 JULY 2012 \\ DOI: $10.1093 / O B O / 9780195396607-0128$
}

\section{Introduction}

The distinctive aspect of phenomenological theories of crime is that they are based upon a stated epistemology: how things are known and a specific ontology - the nature of social reality. This specificity aligns itself with neo-Kantian concern with forms of knowing, interpretation, and meaning, as well as with 20th-century concern with perception, cognition, and the framing of events. While there are influences of phenomenological thinking on varieties of theorizing, such as symbolic interactionism, critical theory, queer theory, and gender-based theories of crime, these ideas are refractions and are inconsistent in their reference to and understanding of the foundational phenomenological works. A phenomenological theory assumes that the practices and associated meanings of actors and the responses of others can produce a valid explanation of crime. These cannot be grasped by counting responses to questionnaires or surveys, or positing the "natural attitude" or the "taken for granted" unless these are shown to be working in interaction. It is only by studying how these processes are revealed in and through routine interactions, especially those between the controllers and the controlled, that valid explanations for crime result. The elegance of an explanation is found in its ability to explicate and reproduce the actors' perspective. This is not a "micro" view of interaction: social action is always collective, mutual, and intersubjective. Features of phenomenological theories of crime stand in some opposition to the ruling statistical inference and naive positivism that command social science. Phenomenological theories have at least five features. First, they focus on intentionality over the course of action. The question of interest is how orientation to and action toward objects produces such social objects. It is through gestures, postures, signs, and indicators that elicit a response that a social object is made meaningful. A robbery occurs as the robber first selects a place, targets a person, confronts the person-as-target, and creates the illusion of violence to get the preferred response, handing over money. The sequence produces a "working consensus," a social object, a robbery. It is now a real, shared social fact. Second, they view the field of consciousness or awareness as replete with stimuli cues, empirical indices that are themselves merely appearances, not the relevancies that emerge intersubjectively. These cues must be reduced by means of bracketing to create forms, types, or typifications. These types, in turn, can be identified only through actors' usage. Think in this regard about the meaning of different types of crime as they are experienced (e.g., homicide, rape, burglary, auto theft). Third, these observed gestures, negotiations, indicators, representations, and postures are made intersubjectively meaningful not by "reading minds," but by behavior. And what is done is very often emotionally loaded and full of bodily sensations such as anger, passion, greed, or desire. These emotions are an integral aspect of crimes. Fourth, in the phenomenologically grounded versions of crime, even the objective attitude of the scientist must itself be questioned : How is it possible to create sense of actors' behavior and studying it "objectively" (Heap and Roth 1973, p. 364; cited under Introductory Works)? The answer is to remain true to the observed collective actions and attributions associated with crime. Finally, phenomenological views of crime require an interrogation of action, not attributions of motives. The question is: How is order indicated, sustained, and/or changed in the context of studying things called "crime"? A constant debate is whether and to what extent the actor's view of everyday life is captured, as opposed to a typification, ideal type, or conceptual scheme. This is one of the few areas of social science that acknowledges philosophical foundations during the course of research. Phenomenological theories of crime recognize the ongoing nature of what is deemed criminal, and keep this awareness in the forefront. Please keep this in mind as you conduct your research. The articles and books discussed here are directed toward academics, graduates, and advanced undergraduates. 


\section{Introductory Works}

A phenomenological theory of crime must be assembled because there is no single statement that draws together the insights of philosophers who frame the ideas and of social scientists who study crime. The identified ideas must be connected by inference with authors and traditions, distinguished from criminological perspectives per se and from members of the "family" of phenomenological sociologies (Douglas 1970, Heap and Roth 1973, Maynard and Clayman 1991, Psathas 1973, Tiryakian 1962). This process of making connections is needed in part because the relevant philosophical background of the authors' work is often unacknowledged by criminologists, and because connections between traditional philosophic questions and everyday sociology have not been elucidated. Modern social science is rooted in positivism and pragmatism. This background elevates the scientific method above other approaches to knowledge and emphasizes the processes by which results are produced. Phenomenological analyses, by contrast, emphasize the ordering and meaning of concrete particulars as they are made sensible. While core ideas are discussed in this article, detailed distinctions between and among the ideas of Husserl and Heidegger and later scholars such as Sartre, Merleau-Ponty, Derrida, and Foucault are not undertaken here because the focus is upon theorizing crime (for background, see Moran 2000 and Zaner 1970).

\section{Douglas, Jack D., ed. 1970. Understanding everyday life: Toward the reconstruction of sociological knowledge. Chicago:} Aldine.

The earliest collection of sociological essays based on the phenomenological perspective, derived from research, and striving to explicate the patterns of analysis that would lead the way into continuing research. Douglas provides a clear and engaging essay to introduce the book, and many of the scholars who shaped the perspective (Weider, Zimmerman, Douglas, Blum, Cicourel, and others) are included. This book, along with Garfinkel 1967 (cited under Emergence of a Sociological Phenomenology), is the best sociological introduction to the topic.

Heap, James L., and Phillip A. Roth. 1973. On phenomenological sociology. American Sociological Review 38.3: 354-367. A brief, dense. scholarly article that is a detailed examination of competing phenomenological sociologies and their nuances. The authors criticize and reject the phenomenological sociologies of other authors (Tiryakian, Bruyn, and Douglas). It is a rather technical article and is an early effort to sort out approaches to the phenomenological world. In a final section, the authors argue for a version derived from ethnomethodology, claiming it as the preferred style of doing sociological work. Available online for purchase or by subscription.

\section{Maynard, Douglas W., and Stephen E. Clayman. 1991. The diversity of ethnomethodology. Annual Review of Sociology 17.1: 385-418.}

An exposition and critique of the branches of ethnomethodology, a primary version of phenomenological sociology. The review, which is very readable and was written for advanced students and scholars, includes a review of studies of conversational analysis, theory, institutional settings, applied social research, and the sociology of science. The authors explain that the aim of work in this perspective is to explain the achieved orderliness of everyday activities and the organizational features of direct interaction. Available online for purchase or by subscription.

\section{Moran, Dermot. 2000. Introduction to phenomenology. London: Routledge.}

A clear and concise introduction to phenomenological philosophies, intended for undergraduates and others interested in the groundwork and fundamental ideas that drove the movement and how these were transformed in the 20th century. Chapters include materials on Brentano, Husserl, Heidegger, and later thinkers such as Gadamer, Arendt, Levinas, Sartre Merleau-Ponty, and Derrida. 
Psathas, George, ed. 1973. Phenomenological sociology: Issues and applications. New York: Wiley.

A very well-edited collection of articles on phenomenological sociology, which are well introduced by Psathas. The introduction deftly connects the fundamental concepts, the natural attitude, typification, the life world and its constitutive elements, and intersubjectivity to the articles assembled in the book. The articles range from theoretical overviews to closely observed ethnographic works cast in the phenomenological tradition.

Tiryakian, Edward A. 1962. Sociologism and existentialism: Two perspectives on the individual and society. Englewood Cliffs, NJ: Prentice-Hall.

An excellent attempt to integrate sociological thinking derived from Durkheim with existentialism.

\section{Zaner, Richard M. 1970. The way of phenomenology: Criticism as a philosophical discipline. New York: Pegasus.}

An accessible introduction for students and social scientists interested in the background ideas that shaped the sociological concern for crime and deviance.

\section{General Overviews}

The new science of sociology and its adjunct, criminology, emerged from traditional philosophy in the late 19th century and were advanced as an empirical basis for understanding social order. How do we know the world and its constitutive parts? How is order indicated, recognized, and put together intersubjectively? Traditional modes of science and mathematics beg the question of how what is known is known: they are not interpretative; their abstract terms failed to grasp the new reality that was unfolding involving race, national destiny, and progress. Initially, much was made of metaphors drawn from biology and the physical sciences, but these were eventually replaced by theories based on action understood at the intersubjective level. These theories drew on phenomenology. Phenomenology, merging in the early 20th century with writings of the German philosopher Edmund Husserl (Husserl 1982) and his student Martin Heidegger (Heidegger 1967), represented an effort to move speculation about knowledge radically in the direction of focusing on the concrete particulars that can be grasped, acted on, responded to, and confirmed over the course of interactions. It has had enormous influence in fiction, mathematics, and philosophy. General overviews are available (Gurwitsch 2009a, Gurwitsch 2009b, Gurwitsch 2010, Spiegelberg 1965). The ideas are also associated with the interpretive movement in German idealism, especially works of Max Weber, Karl Jaspers, Karl Mannheim (Mannheim 1993), and Alfred Schutz (Schutz 1962; Schutz 1967). In effect, German idealism and the philosophic tradition associated with Kant, Hegel, Husserl, and Heidegger drifted onto the American sociological scene, which was and is pragmatic, atheoretical, radically empiricist, and individualistic. In the most powerful version of phenomenological theorizing associated with Harold Garfinkel, the emphasis is on how local order is produced by recognizable practices. These practices are often in contrast with the institutional or organizational and official accounts of what was done-what might be called the presentational strategies (Rawls 2003). For these reasons, phenomenological theories dismiss and reject officially produced data as rerepresentations of the matters of interest; namely, crimes and reaction to crimes. The works included in this section are foundational books that are difficult and detailed; they are best suited to advanced undergraduates, graduates, and academics.

Gurwitsch, Aron. 2009a. Constitutive phenomenology in historical perspective. Vol. 1 of The collected works of Aron Gurwitsch (1901-1973). Edited by Jorge García-Gómez. New York: Springer.

This volume relates constitutive phenomenology to modern philosophy and to the philosophy of the human sciences as well as the natural sciences and was nearly finished when Gurwitsch had to flee to the United States before Germany conquered 
France.

Gurwitsch, Aron. 2009b. Studies in phenomenology and psychology. Vol. 2 of The collected works of Aron Gurwitsch (1901-1973). Edited by Fred Kersten. New York: Springer.

This volume contains major papers of Gurswitsch's, focused on social-psychological studies that draw on the work in psychiatry of Kurt Goldstein and relate phenomenology to René Descartes, William James, Immanuel Kant, and tendencies in modern thought, thus complementing the historical perspectives of Volume 1 (Gurwitsch 2009a).

Gurwitsch, Aron. 2010. The field of consciousness: Phenomenology of theme, thematic field, and marginal consciousness. Vol. 3 of The collected works of Aron Gurwitsch (1901-1973). Edited by Richard M. Zaner and Lester Embree. New York: Springer.

A highly detailed, difficult, and often-obscure set of papers by one of the major figures in the movement. This collection is designed for advanced students of philosophy, with an interest in phenomenology. Gurwitsch's work and his interactions with Garfinkel have had important and profound influence on the field.

Heidegger, Martin. 1967. Being and time. Translated by John Macquarrie and Edward Robinson. London: Blackwell. Being and Time, originally written in German and translated into English, is monumental, difficult, a classic, and certainly one of the most influential books in 20th-century philosophy. It should be read only after mastering introductory overviews. Heidegger argues that the basis of philosophy should be the intuitive experience of phenomena (what appears before us) that, bracketed, will yield that from which order and meaning arises. This order is "transcendental" or semiuniversal. Because we seize on appearances, we fail to grasp the deeper meaning of life and approaching death. Philosophy must understand not only being but how being blinds us to understanding the nature of reality.

Husserl, E. 1982. Ideas pertaining to a pure phenomenology and to a phenomenological philosophy first book: General introduction to a pure phenomenology. Translated by Fred Kersten and André Schuwer. The Hague: Nijhoff.

Husserl sought description of particulars that might yield an epistemology or way of knowing intentional acts directed to the social world of a general sort, such as belief, love, and sadness, and that could be related to that which is believed, loved, and so on. This connection was social and relied on bracketing. Later, Husserl sought to connect the essences in pure consciousness. These ideas frame the natural attitude of the actor. First printed in 1913 (Halle, Germany: Max Niemeyer).

Mannheim, Karl. 1993. From Karl Mannheim. 2d ed. Edited by Kurt Wolff. New Brunswick, NJ: Transaction.

Mannheim was one of the most important German idealists who formed a bridge between traditional philosophical concerns and systematic sociological research in politics, ideology, art, and communication. This collection of his papers, assembled by a leading phenomenologist, Kurt Wolff, includes the very important "Interpretation of Weltanschauugen." This paper, cited by Garfinkel, outlines the approach to indexicality that features as a central concept in serious phenomenological work.

Rawls, Anne Warfield. 2003. Harold Garfinkel. In The Blackwell companion to major contemporary social theorists. Edited by George Ritzer, 122-153. London: Blackwell.

Rawls, a leading social theorist, knows Harold Garfinkel's work and has the enviable capacity to explicate and clarify his dense arguments. This chapter will be useful for any student of the ideas outlined in this bibliography, as well as for anyone interested 
in the development of Garfinkel's ideas from his early days as a student at the University of North Carolina through his work at UCLA.

Schutz, Alfred. 1962. The problem of social reality. Vol. 1 of Collected papers. Edited by Maurice A. Natanson. The Hague: Nijhoff.

These papers contain Schutz's fundamental early ideas, providing a large collection of his work accessible in a single volume.

Schutz, Alfred. 1967. The phenomenology of the social world. Translated by George Walsh and Frederick Lehnert. Evanston, IL: Northwestern Univ. Press.

Schutz is an Austrian philosopher who came to the United States and whose ideas influenced Parsons and Garfinkel. He sought to define the natural or "common-sense" attitude of the actor, his or her intentionality, forms of consciousness, types, and the individual's role in social interaction. His foundational ideas were based on the idea that to understand actions one had to see it as produced by the actor (as a type, not as a person), not by a scientist with a "scientific attitude."

\section{Spiegelberg, Herbert. 1965. The phenomenological movement: A historical introduction. 2 vols. The Hague: Nijhoff.}

Essential reading for serious scholars of this movement, and a daunting challenge for even the most patient reader. The most comprehensive overview and analysis of the movement, couched in the philosophical trends from which it emerged and developed.

\section{Phenomenological Research Resources}

As you, the reader, read this sentence, you are conducting phenomenological research as you consider which of these resources are relevant to your research. These sources provide easy access to rich, contextual objects that will facilitate further study.

Meta: Research in Hermeneutics, Phenomenology, and Practical Philosophy. 2009-.

This resource is topically oriented toward researchers looking for interpretive approaches and techniques associated with the study of experience.

\section{Organization of Phenomenology Organizations.}

This site is topically oriented toward researchers in organizations.

\section{Phenomenology Online.}

A lively, active source of current experiences for study. 
This site is topically oriented toward researchers actively conducting phenomenological studies.

\section{Smith, David Woodruff. 2011. Phenomenology. In The Stanford encyclopedia of philosophy. Edited by Edward N. Zalta.}

The Stanford Encyclopedia of Philosophy is designed so that each entry is maintained and kept up to date by an expert or group of experts in the field. This entry on phenomenology is a brief summary of the field, with good bibliographic leads for further investigation.

\section{What Is Phenomenology?}

This resource covers the seven widely accepted features of the phenomenological approach, the hundred-year spread of phenomenology according to nations and disciplines, tendencies and stages within philosophical phenomenology thus far, and phenomenology into the 21 st century.

\section{Philosophically Oriented Journals}

In any field of social science, there are journals that have been influenced by the phenomenological movement and published articles included by or in the direct tradition of this perspective. Consider searching WorldCat; the results presented to the researcher are some 273 journals in reference to the term "phenomenology." Sifting through these would give the researcher a well-grounded knowledge in phenomenological research, but it might also take a few years. To cut down on that time significantly, the journals presented here are known for their commitment to publishing articles in the phenomenological tradition, well grounded in philosophical considerations. These will prepare the researcher for taking on any phenomenological approach to studying crime.

\section{Bulletin D’analyse Phénoménologique. 2005-.}

This open-access journal promotes research in phenomenology by the diffusion of texts devoted to classical and contemporary philosophical problems, mobilizing resources from the descriptive phenomenological method.

\section{Continental Philosophy Review. 1998-.}

Elicits discussions of fundamental philosophical problems and original approaches to them. With a wide array of interests, this journal covers both expressly theoretical topics and topics dealing with practical problems that extend to the wider domain of sociopolitical life. It encourages explorations in the domains of art, morality, science, and religion as they relate to specific philosophical concerns. Published as Man and World from 1968 to 1997.

\section{Human Studies. 1978-.}

A quarterly journal dedicated primarily to advancing the dialogue between philosophy and the human sciences. Coverage addresses the logic of inquiry, methodology, epistemology, and foundational issues in the human sciences, exemplified by original empirical, theoretical, and philosophical investigations. 


\section{Indo-Pacific Journal of Phenomenology. 2001-.}

As an initiative of the Phenomenology Research Group based in Western Australia and in South Africa, with a long-established phenomenological tradition, this journal focuses on a range of research interests that cross a broad spectrum of areas, including education, health, religion, business, tourism, counseling, and psychology, through the unifying force expressed as a commitment to phenomenology as a research methodology.

Janus Head: Journal of Interdisciplinary Studies in Literature, Continental Philosophy, Phenomenological Psychology, and the Arts. 1998-.

An interdisciplinary journal that places emphasis on the intersections among literature, continental philosophy, phenomenological psychology, and the arts.

\section{Journal of the British Society for Phenomenology. 1970-.}

Advances publications and book reviews in the field of phenomenology, contemporary European philosophy, social philosophy, aesthetics, hermeneutics, and other associated branches of philosophical research.

\section{Newsletter of Phenomenology. 2002-.}

A weekly online newsletter that includes up-to-date information regarding the most-important events in the field of phenomenology.

\section{Phenomenology and the Cognitive Sciences. 2002-.}

Offers a forum for illuminating the intersections among phenomenology, empirical science, and analytic philosophy of mind, by building bridges between Continental phenomenological approaches in the Husserlian tradition and disciplines that have not always been open to or aware of phenomenological contributions to understanding cognition and related topics.

\section{Phenomenology \& Practice. 2007-.}

This journal is dedicated to the study of the lived experience of a broad range of human practices.

\section{Philosophy of the Social Sciences. 1971-.}

Presents discussions focused on the central issues of the social sciences, including general methodology (explaining, theorizing, testing), the application of philosophy (especially individualism vs. holism), the nature of rationality, and the history of theories and concepts.

\section{Studia Phaenomenologica. 2001-.}

A peer-reviewed yearbook in phenomenology and hermeneutics, edited by the Romanian Society for Phenomenology. 


\section{Other Phenomenologically Oriented Journals}

Once the researcher is well grounded in phenomenology's philosophical tradition, it is time to "dig" into the plethora of social science in search of that elusive empirical support. In honor of this search, consider the sample drawn from WorldCat's some 273 results. These journals are not strictly based in the philosophical orientation, but they tend to present phenomenological research of interest. Although studies of crime are less frequent, they are most likely to be found in the following journals.

\section{International Journal for the Semiotics of Law. 1988-.}

Presents discussions that critique, apply, and engage with semiotics or related theory and models of analyses. Some discussions also include topics such as rhetoric, history of political and legal discourses, philosophy of language, pragmatics, sociolinguistics, deconstruction, and all types of semiotics analyses, including visual semiotics.

\section{Journal of Contemporary Ethnography. 1972-.}

As a forum for research using ethnographic methods for examining human behavior in natural settings, the discussions examine a broad spectrum of social interactions and practices-in subcultures, cultures, organizations, and societies.

\section{Journal for the Study of the Theory of Behavior. 1971-.}

Advances understandings of social behavior; that is, people acting in relation to, or being constituted through, the social world of other people, institutions, and material and symbolic culture, by challenging theoretical assumptions, stimulating the development of new and productive theoretical approaches, and translating those advances into innovative methods for research.

\section{Language in Society. 1972-.}

Focusing on sociolinguistics in terms of language and discourse as aspects of social life, this journal publishes empirical articles of general theoretical, comparative, and methodological interest to students and scholars in sociolinguistics, linguistic anthropology, and related fields.

\section{Organizational Studies. 1990-.}

This journal focuses on presenting theoretical and empirical research with the aim of promoting the understanding of organizations, organizing, and the organized in and between societies.

\section{Qualitative Sociology.1978-.}

Focuses on the qualitative interpretation and analysis of social life. With discussions both of theoretical and analytical research, it also expands the discussion of manuscripts based on research methods such as interviewing, participant observation, ethnography, historical analysis, content analysis, and others that do not rely primarily on numerical data. 


\section{Symbolic Interaction. 1977-.}

Showcases empirical research and theoretical development for the Society for the Study of Symbolic Interaction, with studies in qualitative, especially interactionist, research occurring throughout the fields of sociology, social psychology, communication, education, nursing, organizations, mass media, and others.

\section{Emergence of a Sociological Phenomenology}

The social foundations for the research on crime discussed here can be traced to the phenomenological movement. In many respects, the work of Harold Garfinkel (Garfinkel 1952), a student of Talcott Parsons who was influenced by Husserl, Gurwitsch, and Schutz, marks the beginning of a sociological version of phenomenology. Garfinkel's earlier essays and monographs have been edited and introduced by Anne Warfield Rawls (see Garfinkel 2002, Garfinkel 2006, Garfinkel 2008). Garfinkel's students and those directly influenced by him at branches of the University of California at Los Angeles, Santa Barbara, and Irvine produced an impressive body of research. Garfinkel's most cited work is "Conditions of Successful Degradation Ceremonies" (Garfinkel 1956), which outlines the conditions under which a person is stripped to essential emptiness and made a nonperson by the actions directed toward him or her. The idea is dramatically illustrated in Goffman 1961, a study of total institutions (cited under The Labeling Approach). The locus classicus of Garfinkel's work is a collection of essays, Studies in Ethnomethodology (Garfinkel 1967). Here, he writes that ethnomethodology refers to "the investigation of the rational properties of indexical expressions and other practical actions as contingent ongoing accomplishments of organized artful practices of everyday life" ( $p$. 11). Indexical here refers to the multiple and unspecifiable range of meanings produced by any given phrase, word, or symbol. These indexical matters need clarification for any continuous interchange to occur. These clarifications arise through and by practices-exchanges, questions, gestures, and postures: they are organized and they "fill in" or point to what is unsaid. Because meaning is hinged on indexical expressions that must be clarified, concepts posited in advance may fail to capture the order that arises. Garfinkel's struggles with language are in part a result of his wish to somehow move away from the assumptions of analytic and a priori concepts such as roles, values, beliefs, or other things that are abstract glosses on particular concrete, interactional practices. Concepts obscure the details of modes of making sense: ways that through talk and action the social object is somehow shared. Consider three ways in which crime as a social object is defined: as a product of the concerted actions that police take while arresting and coercing citizens, as self-reports of high-school students, and as observed by a researcher in the field. Garfinkel's unique, difficult, and strikingly original work (see especially Garfinkel 1988), placing him with Goffman as the major theorist of the late 20th century, maintains a still-unfolding influence in the United States and abroad. Garfinkel emphasizes the ways through mutual exchanges that intersubjective order is established and maintained. Any theorizing in his view must be based on this foundational matter. These selections provide an important bridge between theorizing in philosophy and the social sciences and are for the serious student and academics.

\section{Garfinkel, Harold. 1952. The perception of the other: A study in social order. PhD diss., Harvard Univ.}

Garfinkel's dissertation compares in elaborate detail the ideas of Schutz and Parsons with respect to role, types, and other concepts and then presents his experimental findings, showing that actors' attribution of meaning is not captured by standard experimental methods.

Garfinkel, Harold. 1956. Conditions of successful degradation ceremonies. American Journal of Sociology 61.5: 420-424.

A brilliant and elegant outline for exploring the ways in which the definition and intentionality of a process shape the identity and placement of a human being in the social-life world from a total identity into an identity that is lower in the group's scheme of types. The conditions under which such degradation works are explored and put in organizational context. Available online for purchase or by subscription. 
Garfinkel, Harold. 1967. Studies in ethnomethodology. Englewood Cliffs, NJ: Prentice-Hall.

This collection is a powerful effort to reconstitute sociology as the study of ethnomethodology. Included in the book are papers defining ethnomethodology, as well as on trust, routine grounds of everyday activities, a sex change and its anomalies, good organizational reasons for bad records, and a very important brief article on rational decision making. The "routine grounds" chapter is fundamental and introduced many scholars to Garfinkel's ideas.

Garfinkel, Harold. 1988. Evidence for locally produced, naturally accountable phenomena of order, logic, reason, meaning, method, etc. in and as of the essential quiddity of immortal ordinary society, (I of IV): An announcement of studies. Sociological Theory 6.1: 103-109.

This is a very useful outline of his ideas and a listing of a large body of research that Garfinkel defined as being carried out within the framework of ethnomethodology and grounded in real-world practices. Available online for purchase or by subscription.

Garfinkel, Harold. 2002. Ethnomethodology's program: Working out Durkheim's aphorism. Edited by Anne Warfield Rawls. Lanham, MD: Rowman \& Littlefield.

Rawls has assiduously gathered together Garfinkel's papers over a thirty-five-year period, some prior to and some after the publication of Studies in Ethnomethodology. The subtitle refers to Durkheim's assertion or aphorism that sociology should focus on the concrete particulars of social facts. It is a collection divided into three parts: the editor's introduction, "What is Ethnomethodology," and "Instructed Actions." The introduction is clear and helpful. Its purpose is not only to explain the aims and scope of Garfinkel's work but also to put it in the context of its reception. The term ethnomethodology emerged from Garfinkel's deeply reflexive studies (pp. 2-7).

Garfinkel, Harold. 2006. Seeing sociologically: The routine grounds of social action. Edited by Anne Warfield Rawls. Boulder, CO: Paradigm.

Framed by an introduction by Rawls, which lays out how Garfinkel post-Harvard moved from theoretical writing to the specification of a study of practices, the other parts of the book consider Garfinkel's writing, "Principal Theoretical Notions," and "Specific Problems." The first part puts in context what Garfinkel sees as the need to work out new concepts because the other concepts reified and made theoretical the practical ways people made sense of complexity.

Garfinkel, Harold. 2008. Toward a sociological theory of information. Edited by Anne Warfield Rawls. Boulder, CO: Paradigm.

Rawls again has fashioned a very clear exposition of a longish monograph, "Memo Number Three," written for an undergraduate course Garfinkel was teaching at Princeton. Part of the memo is omitted, and it is accompanied by five appendices, which were efforts to refine his arguments developed in the previous ten years. The memo, 125 pages in print, is the most systematic treatment of information theory (and its flaws) available.

\section{English Views}

Garfinkel's influence on theorizing crime and deviance first bore fruit in England, at Manchester University and Goldsmiths College of the University of London (Filmer, et al. 1973). In the same phenomenological tradition is the early defining work of 
Taylor, et al. 1973. Filmer et al. 1973 attempted to adapt a version of Garfinkel's ideas by seizing on the importance of routine grounds, typifications, interpretive work, and to a lesser degree sociolinguistic analyses. The mobilization of interest in England remained a function of the intuitive efforts of Terence Morris's students at the London School of Economics: Stan Cohen (Cohen 1972), whose "mods and rockers" drama has become a mini-classic of collective behavior, Jock Young (Young 1971), who adapted systems theories to the contingencies of drug taking and responses to it, and Paul Rock's study of debtors and efforts to collect debt (Rock 1973). These studies combine ideas drawn from symbolic interaction (see Rock 1979) and the subtleties of a broadly based phenomenology. Although somewhat dated, these selections are readable, rich in detail, and informative. They provide one of the baselines of early empirical work in the phenomenology of crime.

\section{Cohen, Stan. 1972. Folk devils and moral panics: The creation of the Mods and Rockers. London: MacGibbon and Kee.}

Stan Cohen's work is a study of the clashes between well-dressed young men, "Mods," and their cultural adversaries, "Rockers," at Brighton, an English seaside resort, in the late 1960s. It combines ideas from collective behavior, labeling theory, and a dynamic notion of feedback and distortion via media amplification. Essential reading for students of this perspective-readable, engaging, detailed, and sophisticated theoretically. This work complements Young 1971.

Filmer, Paul, Michael Phillipson, David Silverman, and David Walsh. 1973. New directions in sociological theory. Cambridge, MA: MIT Press.

An important, early effort to outline a phenomenological approach to social theory that was influenced by the ideas of Cicourel and Garfinkel.

\section{Rock, Paul E. 1973. Making people pay. London: Routledge.}

A study of debt and debt collection, focusing on the social control of debtors in England in the early 1970s.

\section{Rock, Paul E. 1979. The making of symbolic interactionism. London: Macmillan.}

Rock presents here an ideal introduction to problems of theorizing deviance and to symbolic interactionism more generally; a very carefully written book modulating phenomenology and symbolic interaction-a very fair and at times elegantly written and balanced overview. Somewhat dated but still a useful introduction for undergraduates and those unfamiliar with symbolic interactionism.

Taylor, lan, Paul Walton, and Jock Young. 1973. The new criminology: For a social theory of deviance. London: Routledge. Sets out a new and engaging theory of crime that is sympathetic to the Durkheimian tradition, sees crime as an extension of working-class men's lifestyles, and flavors the entire argument with a modified, culturally influenced Marxism.

\section{Young, Jock. 1971. The drugtakers: The social meaning of drug use. London: MacGibbon and Kee.}

This now-classic study examines drug taking, using a systematic collective-behavior model of feedback, distortion, and amplification by the media in England. The book is ethnographically very rich, a portrait of a time and place and an extension of the sociology of everyday life. This is labeling theory with a cognitive twist-and a required read for any reader interested in deviance and crime. 


\section{The Labeling Approach}

Labeling theory, a view that deviance and crime are products of interactions between putative deviants and controllers, not the behavior of "criminals," burst on the scene in the early 1960s. Ironically, labeling theory emerged through the work of anthropologists. The influence of sociologist-anthropologist Edwin Lemert, one of the key figures in such theorizing, came through his framework as used in Goffman 1961. Lemert 1951 soon became a classic. Lemert 1972, a subsequent collection of Lemert's innovative and often-brilliant essays, includes a major statement of the author's theoretic perspective paper, "A Systematic Study of the Check Forger," which is arguably the finest brief paper on the phenomenology of deviance, combing emotion, action, response, and self-response. Lemert's idea of secondary deviance-that is, the self-definition of self as "deviant" as a result of internalizing the reactions of others to initial, rather desultory or occasional violations of tacit or legal norms or rules-was adopted loosely in the 1960 s by Becker (see Becker 2008), who emphasized the sequential, career-like nature of deviance. These ideas-labeling, career as a sequence of steps, and the tendency for the steps to be irreversiblebecame a dogma by the late 1970s (Manning 1975). These and other topics about which Becker wrote stimulated the work of many hundreds of students, colleagues, and scholars in North America, France, Germany, and elsewhere and were called "labeling theory." Becker 2008 became one of the most frequently cited books in criminology and continued to be cited frequently for over thirty years. In Becker's studies, the intentionality of the actor was seen as becoming essentially deviant through a natural history or a process emerging from the reactions and responses of others that grounded the actor in a deviant or criminal context, coloring and shaping his or her choices, emotions, and self-view. In this body of literature the anomalies and contradictions of the philosophic grounding were made secondary; the appearance/essence issue was avoided; bracketing was seized on as how the identity became isolated, coherent and adhesive; and process was elevated above the natural attitude and its problematics. Studies of particular acts of control and how they produced deviance were foreshadowed by Douglas's work on suicide (Douglas 1967). In effect the sheer originality of Lemert, Garfinkel, and Goffman blinded other sociologists to the origins of the ideas they now treated as aspects of a muted, symbolic, interactionist, self-based theory. In this sense, the efflorescence of the late 1960s and early 1970s is borderline phenomenology, and the development of the various versions of ethnomethodology represents a distinct strand of work. These sources are accessible to undergraduates, graduates, and scholars.

\section{Becker, Howard S. 2008. Outsiders: Studies in the sociology of deviance. London: Free Press.}

Often cited, well written, the book uses "outsiders" as a metaphor for various ways of straying from the path of conventionality. A tidy ensemble of essays written by Becker in previous years is wrapped up by an introductory essay that sees deviance as a product of a series of steps, responses, or labels. Deviance is the result of a way of seeing and a product reaction to diverse behavior. It is phenomenological in the resort to typification and the breaking of everyday life assumptions, and it is deviance as the result of a constitutive process. It remains basic reading for all-from undergraduates to serious scholars.

\section{Douglas, Jack D. 1967. The social meanings of suicide. Princeton, NJ: Princeton Univ. Press.}

An important analytic study that elaborates, criticizes, and elaborates Durkheim's classic work on suicide; an essential groundbreaking work that is necessary reading for scholars of deviance and crime.

Goffman, Erving. 1961. Asylums: Essays on the social situation of mental patients and other inmates. Garden City, NY: Anchor.

Perhaps the most cited part of the mosaic that became labeling theory. Deeply phenomenological, with reference to the two life worlds of patients and staff/doctors: it sees labeling and reaction, typification, degradation, and embarrassment as fundamental processes. Goffman sees the institutional bureaucratic order as a façade that facilitates subtle but powerfully coercive interactional control. 
Lemert, Edwin M. 1951. Social pathology: A systematic approach to the theory of sociopathic behavior. New York: McGraw-Hill.

Unique, original, powerful book for scholars, with chapters on various sorts of deviance and their control. The chapter on mental illness is amazingly farsighted, seeing it as a product of institutional processes, not individual constitution or genes. Progenitor to Goffman 1961 and Scheff's later work Being Mentally III: A Sociological Theory (Scheff 1999, cited under Foundational Research), which examines the social processes that produce and sustain mental illness.

Lemert, Edwin M. 1972. Human deviance, social problems, and social control. Englewood Cliffs, NJ: Prentice-Hall. Lemert develops the central idea of "active control," by which he means that institutional processes shape, identify, label, and maintain a category of people perceived to be outside the boundaries of normality. The collection is fundamental reading in the field of the phenomenological theory of crime and deviance, in part because it is cross-cultural and context sensitive.

Manning, Peter K. 1975. Deviance and dogma: Some comments on the labelling perspective. British Journal of Criminology 15.1: 1-20.

A criticism of labeling theory and a call for more comparative, historical, and systematic studies within the perspective. It came near the end of the influence of labeling theory and was something of a funeral oration. Available online for purchase or by subscription.

\section{Foundational Research}

Emerging from similar influences, readings, and interactions, such as those between Garfinkel and Goffman in California and English scholars, the late 1960s marked the beginning of an explosion of research-based studies that combined a concern for order, deviance, and crime and were loosely fitted together as labeling theory. These works included several that have become classics: Cicourel 1995, a study of the classification and typifications of youths in Southern California; Scheff 1999; and Egon Bittner's monograph Functions of the Police in Modern Society (included in Bittner 1990). Cicourel was influenced by Garfinkel while at UCLA; Bittner was Cicourel's student at UCLA and coauthored with him (Cicourel 1995), while Scheff was a student of Goffman's at the University of California at Berkeley. Pollner 1978, in part based on research in a traffic court, challenges the labeling idea by focusing on the reflexive ways in which the court produced processual activities or labels. David Sudnow, author of Passing On (Sudnow 1967), was influenced by George Psathas at Washington University and then by Garfinkel in seminars Garfinkel led at Boston University in the 1970s. A truly original study of this period, soon to have a profound if not lasting influence on studies of what was called "juvenile delinquency," was Matza 1990, which emphasizes the tension between conventional values and street values that were managed situationally and created the conditions of drift into crime. In summary, in each of these studies, concepts drawn loosely from phenomenology were filtered through and perhaps strained by the influences of symbolic interaction. However, they stand out for their focus on the ground and the shifting aspect of intention, typifications, degradation, and emotional stripping of deviance, and their attempt to consistently "bracket" or set aside the attributions associated with those labeled. The argument was, in essence, that patterns of control and reaction reified or solidified the deviant more than their social features or behavior alone. This bracketing provides the fresh quality of these studies. They reveal the ordering that goes on "beneath" institutionally produced accounts and presentational strategies. These are accessible and readable studies for all who are interested in phenomenological theories of crime.

\section{Bittner, Egon. 1990. Aspects of police work. Boston: Northeastern Univ. Press.}

The originality of Bittner's conception of policing hinges on the definition of policing as the application of coercive force to any 
matter that requires intervention now. This is the core police skill and the source of their craft. It is critiqued in detail in Brodeur 2010 (cited under the Social Organization of the Control of Crime. This collection of Bittner's work should be required reading for all who are interested in policing, crime, and organizational analysis.

\section{Cicourel, Aaron V. 1995. The social organization of juvenile justice. New Brunswick, NJ: Transaction.}

An important field study of the policing: categorization, profiling, and recording of police interactions with juveniles in two Californian cities. Cicourel argues that it is necessary to see the context of natural decision making within which gestures, postures, discourse, and recordings of "data" are known. Juveniles are characterized via folk wisdom and bureaucratic procedures. Thus, social control is a commonsense attribution.

\section{Matza, David. 1990. Delinquency and drift. New Brunswick, NJ: Transaction.}

Juveniles are swept away in the tensions and anomalies of the moment. Youth act, react, rethink, and account for later actions that were exciting, collective, and arousing. Youth do not choose to become delinquents; they drift into actions that are exhilarating and remarkable in otherwise mundane lives. They neutralize and account for their actions, as do the middle class.

\section{Pollner, Melvin. 1978. Constitutive and mundane versions of labeling theory. Human Studies 1.1: 269-288.}

A clear statement of the differences between the phenomenological and symbolic interactionist views of crime and deviance, based on the central notion of reflexivity. Available online for purchase or by subscription.

\section{Scheff, Thomas J. 1999. Being mentally ill: A sociological theory. 3d ed. Chicago: de Gruyter.}

The author takes a radical view of mental illness: it is a function of trivial, tacit violations of expectations that are jarring or out of place and actions that are seen in courts as evidence of deeper problems that require hospitalization. An elaboration of Goffman's moral career of the mental patient in Goffman 1961 (cited under The Labeling Approach), a book that created much reaction and controversy.

\section{Sudnow, David. 1967. Passing on: The social organization of dying. Englewood Cliffs, NJ: Prentice-Hall.}

An ethnographic study of dying and death in two St. Louis Hospitals; class, age, and gender shape treatment. Even the most problematic of matters is here made mundane-reaction of the hospital staff, a set of procedures, outcomes, and records. Communication about death reveals parallels with every other institutional order, with its allusions of equality and contrasting orderly, sense-making concrete work practices.

\section{Goffman's Contribution}

Perhaps the best understood phenomenological analysis of everyday behavior, including aspects of criminal activity, is Goffman's monograph The Presentation of Self in Everyday Life (Goffman 1959), carved out from his dissertation. It remains the most cited and best understood of his works. I think it is safe to say that The Presentation of Self in Everyday Life and Goffman 1961 (cited under The Labeling Approach) have indirectly influenced all contemporary qualitative studies of crime and criminality. Goffman 1961 was a foundational work in the labeling scheme. There are strands in Goffman's work that derive from the utter power of action taken in here and now. An early collection of his essays (Goffman 1967) focuses on the emotional and 
social aspects of risk, "action," and uncertainty that play a major role in criminal activity. In addition, his essay Stigma (Goffman 1963) represents his most systematic examination of degradation, one aspect of the deviant's career. On the other hand, his work can be read as critique of many of the current views of crime: his critique of rational choice, systems theory, and game theory (Goffman 1969) is certainly a neglected and consummate critique of ideas that have distorted views of human action post-World War II. His originality is derived from a combination of negotiated meanings, groundings in interaction, moral framing, and cognitively based systems thinking. If crime is seen as situated action labeled as such, then the interaction order in which crime unfolds is critical. His ideas concerning the independent, foundational nature of the interaction order (Goffman 1983) have shaped subsequent theoretical debate in sociology and criminology (Rawls 1987). The most useful and systematic overview of Goffman's work is Burns 1992. These are all readable and accessible to the educated reader.

\section{Burns, Tom. 1992. Erving Goffman. London: Routledge.}

The most systematic, straightforward, clear, and careful overview of Goffman's works as a whole. It is accurate and comprehensive. Burns, unlike other commentators, does not see Goffman's work as a single unified theory.

\section{Goffman, Erving. 1959. The presentation of self in everyday life. New York: Doubleday.}

Written early in his career, this work is among the most influential books published in social science in the 20th century. Subtle and witty, it is often misunderstood. It makes the case for the power of situated interaction in which impressions are managed. This work draws on the metaphor of the drama to make everyday life comprehensible.

\section{Goffman, Erving. 1963. Stigma: Notes on the management of spoiled identity. New York: Simon \& Schuster.}

A brief, analytic essay on the vulnerability of all persons to the attributions of stigma and their consequences. As an important contribution to the understanding of labels and their emotional and social psychological affects, it is a must-read for those studying crime and deviance.

\section{Goffman, Erving. 1967. Interaction ritual: Essays on face-to-face behavior. Chicago: Aldine.}

A collection of early essays that deal with embarrassment, deference, and demeanor, including an original essay, "Where the Action Is." The essays explore the relevance of risk taking and involvement to the social organization of interaction.

\section{Goffman, Erving. 1969. Strategic interaction. Philadelphia: Univ. of Pennsylvania Press.}

Although the title suggests otherwise, these essays are a powerful critique of rational choice, rational action theories, and game theory. Strategic interaction, from the perspective of Goffman and the mutual, collective, and moral nature of sensible action, is a small and very stylized kind of interaction.

\section{Goffman, Erving. 1983. The interaction order: American Sociological Association, 1982 presidential address. American Sociological Review 48.1: 1-17.}

This succinct summary of Goffman's perspective outlines the case for the fundamental nature of face-to-face co-presence to sociology to show how social structures heavily rely on the interface effects of the interaction order. Available online for purchase or by subscription. 
Rawls, Anne Warfield. 1987. The interaction order sui generis: Goffman's contribution to social theory. Sociological Theory 5.2: 136-149.

In the context of debates over the meaning and importance of the interaction order, Rawls echoes and argues for the importance of Goffman's original ideas, in a call to consider them in their own right. Available online for purchase or by subscription.

\section{Empirical Studies}

The labeling perspective associated with Becker, Lemert, and Goffman built on earlier studies. At the University of Chicago in the 1950s, many of the most important criminologists of their generation were being trained: James Short, Albert J. Reiss, Howard S. Becker, Donald Cressey, Alfred Lindesmith, and Goffman himself. Prior to that, pioneers such as Clifford Shaw and Henry McKay, Robert Park and Ernest Burgess, and E. C. Hughes and Frederick Thrasher were carrying out research. The initial influences on Park were German-namely, Simmel, who came from the German idealist tradition and emphasized the connection between collective action and social forms. This typification tradition remains part of the Chicago tradition and links it to strands of phenomenological thinking concerning politics. Gusfield wrote an important book, Symbolic Crusade (Gusfield 1966), paralleled by a similar book, Edelman 1964, which attempted to lay out the complexities of politics in terms of the meaning of status relationships or group position. This line of thought is the emotional phenomenology of politics, the grounding for the anxieties and fears that groups mobilize to gain power in the face of loss. The prohibition movement, much like the Tea Party movement of the early 21st century, arose from ressentiment (Scheler 1972), disaffection, a sense of loss, a hatred for the dynamics of the present, and a reactionary base. Feelings of rejection of what one desires fuels repeated hatred, reaction, and perhaps crime of an expressive sort. Instrumental crime, intended to gain money, is in Scheler's view (Scheler 1972, p. 65) rational and does not stem from ressentiment. Howard S. Becker (Becker 1974), echoing a theme in Durkheim's work, wrote that deviance is a collective matter as well as an individual matter, especially regarding social movement that is directed toward pressuring law enforcement, adding new laws, or refining the nature of the collective threat. Katz 1988 also connects emotions of excitement and risk as a part of the intentionality of criminal acts. All these works are readable and important elaborations of phenomenological theories of crime.

Becker, Howard S. 1974. Labeling theory reconsidered. In Deviance and social control. Edited by Paul E. Rock and Mary McIntosh, 41-66. London: Tavistock.

The fundamental statement of the labeling perspective, drawing heavily on phenomenological ideas about the role of meaning based in interaction as a source of deviance and deviant careers.

\section{Edelman, Murray J. 1964. The symbolic uses of politics. Urbana: Univ. of Illinois Press.}

An important statement outlining the role of symbols, power, and politics in creating social order, and the importance of expressive symbolization in creating social movements.

Gusfield, Joseph R. 1966. Symbolic crusade: Status politics and the American temperance movement. Urbana: Univ. of Illinois Press.

An analysis of the US prohibition movement, demonstrating how symbolization of status and class drives political movements, especially reactionary movements that seek to return to an idealized past.

Katz, Jack. 1988. Seductions of crime: Moral and sensual attractions in doing evil. New York: Basic Books. 
A book using many topics to illustrate the role of emotions in creating and sustaining criminal acts such as robberies and senseless murder.

Scheler, Max. 1972. Ressentiment. Edited by Lewis A. Coser. Translated by William W. Holdheim. New York: Schocken. An essay in the German idealist tradition that sees emotional feelings of frustration, anger, and lack of fulfillment as bases for systematic and continued dissatisfaction. Scheler divides crime into two types: rational crime such as burglary or robbery that is focused on obtaining wealth or status, and crimes that are merely expressive acts of frustration (e.g., arson).

\section{The Exceptions and Variations}

The empirical studies based on a phenomenological theory waned in the late 1980s, as economic depression and conservative governance emerged with a vicious edge in regard to incarceration and law enforcement (Garland 2001). While the ethnographic exploration of crime continues, it has a more descriptive quality and less direct concern with elaborating theory. These studies are held together by their focus on the practices by which the work of crime is done or is controlled. In this way, at their best, they are cameos one could compare with those of Turgenev, Cezanne, or Sherwood Anderson. For this reason, the grand essays of Foucault (Foucault 1979, Foucault 2006) remain as touchstones rather than studies of crime; they explore the conditions of producing the social object crime and control. Semiotics (Eco 1979) equally remained as exercises in representation rather than description of practices: there is no work on the semiotics of crime as a practice unless one counts descriptive works on graffiti. A fascinating, detailed ethnographic study, Goffman 2009, draws on phenomenological themes in Foucault's work to criticize his notion of the panopticon and the nature of socialization. Goffman 2009 argues that policing of poor black neighborhoods produces a set of wanted men whose lives are patterned by their tactics of avoiding arrest, and that the resultant arrests are incidental to their behavior. Thus, the production of crime is the result of active control in a specified area that is flooded with wanted men and police. These books vary from very dense philosophical writing to works of general interest to students of crime.

\section{Eco, Umberto. 1979. A theory of semiotics. Bloomington: Indiana Univ. Press.}

The clearest and most useful statement of semiotics from a pragmatic perspective-including a typology of signs and the modes of sign production.

\section{Foucault, Michael. 1979. Discipline and punish: The birth of the prison. Translated by Alan Sheridan. New York: Vintage.}

Originally published as Surveiller et Punir: Naissance de la Prison in 1975 (Paris: Gallimard) and translated into English in 1977 (New York: Pantheon), Foucault explores the social and theoretical mechanisms underlying the rise of the prisons, state-based punishment, and discipline in Western penal systems during the modern age, based on primarily French historical documents. The vast applicability of the issues discussed to understanding social control in every modern Western society has made this a seminal work.

\section{Foucault, Michael. 2006. History of madness. Edited by Jean Khalfa. Translated by Jonathan Murphy and Jean Khalfa.} London: Routledge.

Originally published as Folie et Déraison: Histoire de La Folie à L'âge Classique in 1961 (Paris: Plon); translated into English in a partial edition as Madness and Civilization in 1967 (London: Tavistock) and fully translated into English in 2006. Foucault draws on historical evidence of French use of prisons and mental hospitals to demonstrate the arbitrary, historical, and cultural 
patterning of "madness" and mental illness in Western history.

Garland, David. 2001. The culture of control: Crime and social order in contemporary society. Chicago: Univ. of Chicago Press.

An analysis of root causes of the incarceration frenzy of the 1980-1990 period. The marginalization of groups and the criminalization of drug crime as well as reaction to change all contributed to an increase in the prison population. This work is fundamental reading for all who are interested in social control and the phenomenological analysis of crime.

Goffman, Alice. 2009. On the run: Wanted men in a Philadelphia ghetto. American Sociological Review 74.3: 339-357. A fieldwork-based, detailed analysis of modes of police-based social control in high crime areas. Goffman traces out its devastating impact on African American men. A penetrating critique of the overstated Foucaultian view of massive, constant social control by the state. The random and uneven impact of police actions when combined within informal social control produces repeated criminal acts. Available online for purchase or by subscription.

\section{Careers and Crime}

Career studies of criminals trace out the contingencies, turning points, epiphanies, and nadirs of people using a natural history or steps in sequence leading to an outcome. These processes can be done using diaries, letters, interviews, or other records. Such studies have a long history in criminology, extending from Thomas and Znaniecki 1984, Sutherland 1937, and Shaw 1966 in the Chicago school tradition and including later studies such as Klockars 1974. Other writers have described via lengthy interviews the practices of burglars, armed robbers, and killers (Athens 1980, Jacobs 1999, Jacobs 2000, Wright and Decker 1996, Wright and Decker 1997). Data on their history and background complement the analysis of the crimes done. All these studies are basic reading in the area of criminal careers and crime.

\section{Athens, Lonnie H. 1980. Violent criminal acts and actors: A symbolic interactionist study. London: Routledge \& Kegan Paul.}

A unique analysis, based on interviews with killers and armed robbers, of the dynamics and meanings of violent crime.

Jacobs, Bruce A. 1999. Dealing crack: The social world of street corner selling. Boston: Northeastern Univ. Press. A fieldwork-based analysis of the dynamics of dealing crack cocaine in East St. Louis. Jacobs charts the ways in which the faddish and unique features of the drug, the social organization of drug dealing, and police practices eventually led to a diminution in crack use. The rise of massive use is seen as a function of the marginal status of dealers, inexpensive drugs, and uneven police attention to enforcement.

Jacobs, Bruce A. 2000. Robbing drug dealers: Violence beyond the law. Chicago: de Gruyter.

Jacobs uses interview and observational material on drug dealing to analyze how, in the absence of legal social control, dealers rob each other systematically with intent to even scores, protect their business, and obtain cash and guns. An interesting critique of rational-choice views of criminal activities. 
Klockars, Carl B. 1974. The professional fence. New York: Free Press.

This now-classic study in deviant careers is based on interviews with a fence that describe the strategies and tactics of fencesthose who buy and sell the results of burglaries. The book describes the relationships of the fences to burglars and the police, and the fences' rationalization or account for their role in society.

\section{Shaw, Clifford R. 1966. The jack-roller: A delinquent boy's own story. Chicago: Univ. of Chicago Press.}

A well-regarded study of the life of a young man who commits robberies in Chicago in the 1930s. An exploration based on subcultural theory and the social-disorganization perspective that sees values, perceptions, and meanings conducive to crime rooted in the social organization of the city, the values and beliefs of selected areas of the city, and opportunities to commit crime.

\section{Sutherland, Edwin H. 1937. The professional thief: By a professional thief. Chicago: Univ. of Chicago Press.}

A study of the career of a professional thief working in Chicago from 1905 to 1925 . The study emphasizes the roles, language, and subculture of the thief and how he makes sense of and rationalizes his diverse modes of stealing. The study is cast in the work and the self-career framework that organized many studies of occupations cast in the University of Chicago sociology tradition.

Thomas, William I., and Florian Znaniecki. 1984. The Polish peasant in Europe and America. Urbana: Univ. of Illinois Press. The first systematic sociological study of immigration in the United States. A classic work based on personal documents, interviews, and historical records. A work that established the preeminence of the University of Chicago "school" of sociology. First published in 1918 (Boston: Richard G. Badger).

Wright, Richard T., and Scott H. Decker. 1996. Burglars on the job: Streetlife and residential break-ins. Boston: Northeastern Univ. Press.

A partner to their book on armed robbers (Wright and Decker 1997), the authors take an analogous approach to understanding how burglars decide to commit a burglary: choosing a target, entering the target, searching and departing strategies, and disposing of the goods obtained. A final chapter outlines an approach to burglary prevention.

Wright, Richard T., and Scott H. Decker. 1997. Armed robbers in action: Stickups and street culture. Boston: Northeastern Univ. Press.

Based on lengthy interviews with active armed robbers, the book describes the natural history of carrying out an armed robbery: deciding to commit the crime, choosing the target, and committing the offense. A final chapter outlines policies designed to prevent armed robbery.

\section{Phenomenological Methods and Crime}

General issues of phenomenological methods are raised in Schutz 1962 (cited under General Overviews), Kaufmann 1944, and Ihde 1977, while those most directly relevant to criminology are articulated in Cicourel 1995 (cited under Foundational Research). The methodological question of how to capture the "natural attitude" of perceptions, cognition, or intention can be 
seen as simple descriptions of the being in the world of actors as they employ, bracket, typify, and act (Natanson 1963) and studies that inquire into the more perplexing question of how actors do this (Polsky 1967). The methodological question of how to carry out phenomenological studies of crime is addressed in Lindesmith 2008, Cressey 1953, and Znaniecki 1934. This question carried with it a strong critique of the variable-based, statistical-induction approach that has now ravaged sociology, offering an alternative based on identifying the actions and reflections that produced the social object of interest; for example, opiate addiction (Lindesmith 2008) or embezzlement (Cressey 1953), and which actions and reflections are not present in that combination when it does not emerge. In these studies, explanation does not rest on norms, values, or social roles but rather on the ways in which, over time, actors respond to, make sense of, or reject the plausible options in a field. These works, with the exception of Polsky 1967 and Cressey 1953, are recommended only to those deeply interested in methods for conceptualizing and researching studying crime.

\section{Cressey, Donald R. 1953. Other people's money: A study in the social psychology of embezzlement. New York: Free Press.}

An analysis of convicted white-collar criminals (embezzlers) that focuses on their careers: how they define a financial problem, how they see embezzling as a solution to that problem, and how their career unfolds. The framing of the problem and its solution is phenomenological in that they frame and define the action as a rational solution to a perceived problem.

Ihde, Don. 1977. Experimental phenomenology: An introduction. New York: Putnam.

A well-written philosophical analysis of the phenomenological method; a very general and abstract essay.

Kaufmann, Felix. 1944. Methodology of the social sciences. Oxford: Oxford Univ. Press.

A classic statement of the phenomenological method as it applies to the social sciences, as a well as a criticism of statistical reasoning, economic modeling, and radical positivism.

\section{Lindesmith, Alfred R. 2008. Addiction and opiates. New Brunswick, NJ: Transaction.}

A refinement of the method of analytic-induction-based studies of the careers of the opiate addicts; a classic study both in methodological and substantive terms. First published in 1968.

Natanson, Maurice A., ed. 1963. Philosophy of the social sciences: A reader. New York: Random House.

Natanson's collection is the best brief overview of the issues of explanation in the social sciences and includes key readings from logicians, philosophers of science, and social scientists.

Polsky, Ned. 1967. Hustlers, beats, and others. Chicago: Aldine.

One of the finest brief introductions to fieldwork with deviant subcultures, written by an experienced and sophisticated fieldworker.

\section{Znaniecki, Florian. 1934. The method of sociology. New York: Farrar \& Rinehart.}

A treatment of the phenomenological method in the context of social science. It is an essential reading for the student of 


\section{The Field of Crime: Honor and Disrespect}

Studies of crime are set in a field: a set of forces, objective and subjective, that are at play in what is called crime. The centrality of perception to the natural attitude of everyday life, the baseline against which phenomenology operates, is explored in imaginative experiments reported in Ames 1960. These forces interact over the course of action; thus, the controllers and the controlled come into play. When policing is viewed as irrelevant, corrupt, and unpredictable, self-help (Black 1983) is essential. Self-assertion and violence in respect to self-protection predominate in contested interactions. Honor and dishonor involve a claim for respect that may or may not be validated by others. Honor plays an important role in shaping the crimes of the young, and because the young commit most of the acts called crime, it is a key concept in understanding crime and its causes. Honor is an aspect of the sociocultural context (Pitt-Rivers 1967). Horowitz and Schwartz 1974 (also Horowitz 1983) is a study of honor that shows in detail, as does Anderson 1999, that among marginal communities in which respect and honor denied them in the larger society are salient, the practices surrounding maintaining honor and respect and responding to perceived disrespect are powerful. They produce the object, an affront that almost always requires a response. Once an affront is perceived, the aim is to restore a damaged honor. Certainly, there are conditions when indignities can be set aside or bracketed (see Jacobs 1999 and Jacobs 2000, both cited under Careers and Crime). Studies of burglars and armed robbers show that the sequence of deciding, targeting, selecting, acting, and accounting for an action is reflexive, situational, and embedded in a context of emotion (see Wright and Decker 1996 and Wright and Decker 1997, both cited under Careers and Crime). These studies demonstrate that the phenomenological infrastructure of honor, attribution, negotiation, and typification characterizes interaction in areas of cities in which "crime" is one among many visible and invisible features. These studies are primarily for graduate students and scholars, although Horowitz and Schwartz 1974 should be required reading for those interested in gangs and youth crime.

Ames, Adelbert. 1960. The morning notes of Adelbert Ames, Jr.: Including a correspondence with John Dewey. Edited by Hadley Cantril. New Brunswick, NJ: Rutgers Univ. Press.

A social-psychological commentary by a physician and expert on perception and meaning; Ames produced experiments demonstrating the brain's processing of stimuli: contains rich examples of the power of socially shaped cognition.

\section{Anderson, Elijah. 1999. Code of the street: Decency, violence, and the moral life of the inner city. New York: Norton.}

An ethnographic study that depicts the vicissitudes of African Americans trying to lead the good life and struggling against the consequences of crime, drug use, and unemployment. The book is based on extensive fieldwork, interviews, and observations made in Philadelphia.

Black, Donald. 1983. Crime as social control. American Sociological Review 48.1: 34-45.

Black outlines a theory of social control that argues that conduct regarded as criminal is often quite the opposite. Self-help is revenge-based action. To the degree that self-help responds to the conduct of someone else-the victim-as deviant, crime is a form of social control. Available online for purchase or by subscription.

Horowitz, Ruth. 1983. Honor and the American dream: Culture and identity in a Chicano community. New Brunswick, NJ: Rutgers Univ. Press.

An extension of Horowitz and Schwartz 1974, demonstrating how the wish to be honored and respected drives gang behavior 
and leads to compromises to achieve the American dream of financial success.

Horowitz, Ruth, and Gary Schwartz. 1974. Honor, normative ambiguity and gang violence. American Sociological Review 39.2: 238-251.

This article presents an argument based on extensive fieldwork with Chicano gangs in Chicago, demonstrating how honor is defined by the situation in which it is challenged and how honor and respect are critical aspects of gang behavior. Available online for purchase or by subscription.

Pitt-Rivers, Julian. 1967. Contextual analysis and the locus of the model. European Journal of Sociology 8.1: 15-34.

An elegantly argued paper written by an anthropologist famous for his studies of honor. Pitt-Rivers demonstrates with data from Spanish villages the determinant consequences of social context on the meaning of wearing the wide-brimmed sombrero. Available online for purchase or by subscription.

\section{Crime as Reflexive, Sequentially Patterned Action}

Phenomenological theories of crime are not a pure type as the influence of phenomenological themes (see Maynard and Clayman 1991, cited under Introductory Works) is seen in views of crime understood in other contexts-symbolic interactionist (Lofland 1969) or merely qualitative studies. However, as a category, phenomenological crimes focus on collective action, some of which is co-offending (Decker and Van Winkle 1996). The following matters are emphasized: the socio-social crisis or threat that touches off the possibility of committing a crime; the role of intention or the horizon of possibilities that frame the possible target; the context or role of authority or risk; and the action. All the choices are seen in an emotional and largely impulsive frame of reference. These studies distinguish the process of carrying out a crime from the excuses or accounts for the action. Often, these explanations or accounts are neutralizing techniques that rationalize and justify the crime (see Matza 1990, cited under Foundational Research). Jacobs 2000 (cited under Careers and Crime) points out in detail that the unpredictable, uneven, often-violent, and heavy-handed actions of the police ironically disrupt the patterns of self-help that moderate violence among drug dealers and escalate violence within the market. Goffman 1961, which offers a view of the mental patient as a victim of social control, is a model for these studies. These depictions of crime and deciding set them apart from those derived from statistical analyses of official statistics in which such descriptions are absent, as well as from those based on schema of rational choice, anomie, and strain and other social psychological and individualistic theories that attribute such deciding to attitudes, nurturance, or values. They rest on descriptions of action. Phenomenological theories begin with the notion of multiple, overlapping, social realities or worlds that are set apart from each other, while the aforementioned theories assume a coherent, consistent, and single reality that criminals and others inhabit jointly. The power of phenomenological theories lies in their deep understanding of the tensions and conflicts that arise from the often-violent and restricted worlds in which deviants live (Bourgois 2003, Maher 1997). These references are of general interest in the study of crime.

\section{Bourgois, Philippe I. 2003. In search of respect: Selling crack in EI Barrio. Cambridge, UK: Cambridge Univ. Press.}

A detailed ethnographic study of crack cocaine use and dealing in East Harlem, focusing on the life contingencies of five key informants in this social world.

Decker, Scott H., and Barrik Van Winkle. 1996. Life in the gang: Family, friends and violence. Cambridge, UK: Cambridge Univ. Press. 
An ethnographically rich study of gangs, done in the tradition of Thrasher and Shaw and McKay. The study is based on interviews and observations of ninety-nine gang members: their lives, family relationships, recruitment, and leaving of the gang life.

\section{Goffman, Erving. 1961. The moral career of the mental patient. In Asylums: Essays on the social situation of mental patients and other inmates. By Erving Goffman, 125-170. Garden City, NY: Anchor.}

Goffman outlines the stages of the moral career of the mental patient, arguing that at each point where allies and supports are absent or taken away that the person is caught in a "betrayal funnel" and becomes an ill mental patient—partaking in a selffulfilling prophecy.

\section{Lofland, John. 1969. Deviance and identity. Englewood Cliffs, NJ: Prentice-Hall.}

A very clearly written text-like treatment of the labeling perspective that develops a theory of deviance. Heavily relying on symbolic interactionism, it depicts a pragmatic version of how deviance becomes a central source of identity.

Maher, Lisa. 1997. Sexed work: Gender, race, and resistance in a Brooklyn drug market. Oxford: Oxford Univ. Press. A detailed ethnographic study done in New York City that connects drug dealing, sexual exchanges, and policing.

\section{The Social Organization of the Control of Crime}

Crime is a function of some form of active social control (Lemert 1972, cited under The Labeling Approach) when legitimate agencies are responding to behavior. While visible street crime such a drug dealing, robbery, and assault occupy police and concern the public most, crimes that involve the violation of trust, global transnational crimes, crimes against the environment or quality of life, and crimes facilitated by the Internet are increasing. Certainly, academic research in these new forms of crime has increased, and the ambit of near-crimes now includes human rights violations. The nature of response to these crimes has changed because they often do not involve a complainant or victim. The commonsense view of "crime," "privacy," and even "surveillance" is rapidly being transformed. New technologies are modifying police tactics (Manning 2008). The difficulty in controlling new forms of crime phenomenologically is that they are based on a mediated presence; they involve no face-to-face or bodily co-presence; they are carried out at a distance, without the awareness of the victim; their damage is symbolic (e.g., holdings in banks, stocks, "identity," trust); and such crimes are typically called matters of "torts" or remedies rather than crimes and are handled via civil law rather than criminal law. Brodeur 2010 reformulates Bittner 1990 (cited under Foundational Research), claiming that Bittner's argument focuses overmuch on patrol and overemphasizes the importance of force. Brodeur argues policing has changed: he urges the consideration of new forms of control via surveillance and tracking, community policing, and mapping. Grabosky 2007 coined the term "electronic crime" and developed a regulatory approach to such violations and crimes. Leman-Langlois 2008 and Andrejevic 2007 outline new forms of crime and surveillance that look at the social forms of control and surveillance emerging in an electronic age. In this sense, the tradition of phenomenological theories focusing on intentions, actors' typifications, practices, and sense making is reduced in viability even in a theoretical sense. There are no detailed ethnographies of the practices producing these new forms of crime, and they have typically been addressed by political scientists and economists using semi official data. Unlike the visible street crimes that remain the focus of the police, electronic crime as a social object has not been produced. Those interested in the future of crime should read these books carefully. 
As an overview of the role of surveillance in modern life, this work focuses on interactivity, or the relation among technology, resistance, and social power. The book is very critical of the claims of media corporations and advertisers that new technologies will provide more-democratic and equalitarian societies.

\section{Brodeur, Jean-Paul. 2010. The policing web. New York: Oxford Univ. Press.}

Brodeur challenges Bittner's theory with his own subtle theory of policing; a masterful overview of policing in its many facets, public and private, secret and public, uniformed and investigative. Brodeur challenges Bittner's core idea that policing is predicated on the application of violence.

\section{Grabosky, Peter N. 2007. Electronic crime. Upper Saddle River, NJ: Pearson Prentice Hall.}

A brief overview of these new forms of crime, and attempts to regulate them.

Leman-Langlois, Stéphane. 2008. Technocrime: Technology, crime and social control. Cullompton, UK: Willan.

The book contains a set of chapters that speculate about the consequences of new forms of crime and surveillance modalities.

\section{Manning, Peter K. 2008. The technology of policing: Crime mapping, information technology, and the rationality of crime control. New York: New York Univ. Press.}

Manning, in this ethnographic study of crime mapping in three large American cities, challenges the assumption that policing is becoming more efficient and effective as a result of the application of new technologies such as crime mapping and organizational tactics such as CompStat, evidence-based policing, and crime-focused meetings.

\section{Limitations and Critiques of Phenomenological Theories}

The power of labeling theory came from three sources: the reactions to the repressive actions of the state during the civil-rights movement, Vietnam, and election demonstrations; the notion that social control actually "produced" deviants and sustained their status as criminals, deviants, and outsiders; and an implicit critique of the power of the economic and political system to label and marginalize populations categorically. The unfolding idea that deviant status was an almost always irreversible one and was associated with careers that outside control, not criminals' own behavior, had produced was attacked by researchers who argued that those labeled mentally ill were indeed so diagnosed, that criminals learned their criminality as children, that deviants might fight back and reject or neutralize the label, and that criminal statistics may be wrong, misleading, or distorted but they are the best that we have (Rosenfeld 2011). The clear point made from the reaction to labeling theory was the commitment of criminologists to the conventional wisdom about crime: that it was not about state power or differential and arbitrary power; that criminals were either poorly socialized (Gottfredson and Hirschi 1990), good learners (Akers 2009), made rational choices to be criminals (Tittle 1995), or were in some way blocked from opportunities (Passas and Agnew 1997). These last themes dominated criminology since the early 1970 s, crushing the phenomenological moment. These works are intended for advanced graduate students and scholars of the social sciences.

Akers, Ronald L. 2009. Social learning and social structure: A general theory of crime and deviance. New Brunswick, NJ: Transaction. 
Crime, like other behavior, is learned, rewarded, and punished in such a way that individuals become socialized to criminal activity.

Gottfredson, Michael R., and Travis Hirschi. 1990. A general theory of crime. Stanford, CA: Stanford Univ. Press. Proposes a general theory of crime, based on lack of self-control emerging from early familial experience.

Passas, Nikos, and Robert Agnew, eds. 1997. The future of anomie theory. Boston: Northeastern Univ. Press. Blocked from opportunities, people face strain and choose crime as one avenue to achieve their unrealized goals.

Rosenfeld, Richard. 2011. The big picture: 2010 presidential address to the American Society of Criminology. Criminology 49.1: 1-26.

Rosenfeld, in his presidential address, argues for a balance between studies of crime and the structural features that produce crime. Available online for purchase or by subscription.

Tittle, Charles R. 1995. Control balance: Toward a general theory of deviance. Boulder, CO: Westview.

Based on the framework of institutional balance, Tittle argues that a lack of consistent balance between institutional orders in societies causes frustration and blockage, leading to crime.

back to top 